УА $\mathrm{K} 612.214 .16 .012 .1-148.65$

(c) Ю. А. Бандрівський, О. О. Бандрівська, Н. Н. Бандрівська

$\triangle \mathrm{BHЗ} \mathrm{«Тернопільський} \mathrm{державний} \mathrm{медичний} \mathrm{університет} \mathrm{імені} \mathrm{I.} \mathrm{Я.} \mathrm{Горбачевського»}$

\title{
Стан органів порожнини рота при деструктивно-запальних захворюваннях гастродуоденальної зони (огляд літератури)
}

Резюме. Розглянуто проблему участі порожнини рота в розвитку захворювань ШКТ. 3 одного боку, патологія травної системи, змінюючи параметри внутрішнього середовища організму, робить істотний вплив на стан порожнини рота, з іншого боку, згідно з клінічними даними, патологічні процеси в порожнині рота стають вогнищами хронічної інфекції, i, порушуючи акт жування, призводять до порушення фрунції ШКТ і загострення його хронічних захворювань.

Ключові слова: захворювання ШКТ, порожнина рота, карієс, пародонт.

\author{
Ю. А. БанАривский, О. О. Бандривская, Н. Н. Бандривская \\ ГВУЗ «Тернопольский государственный медицинский университет \\ имени И. Я. Горбачевского»
}

\section{Состояние органов полости рта при деструктивно- воспалительных заболеваниях гастродуоденальной зоны (обзор литературы)}

Резюме. Рассмотрена проблема участия полости рта в развитии заболеваний ЖКТ. С одной стороны, патология пищеварительной системы, изменяя параметры внутренней среды организма, оказывает существенное влияние на состояние полости рта, с другой стороны, согласно клиническим данным, патологические процессы в полости рта становятся очагами хронической инфекции, и, нарушая акт жевания, приводят к нарушению функции ЖКТ и обострению его хронических заболеваний.

Ключевые слова: заболевания ЖКТ, полость рта, кариес, пародонт.

\author{
Yu. L. Bandrivsky, O. O. Bandrivska, N. N. Bandrivska \\ SHEI «Ternopil State Medical University by I. Ya. Horbachevsky» \\ Condition of the oral cavity in destructive inflammatory \\ diseases of gastroduodenal area (literature review)
}

Summary. The problem of oral participation in the development of gastrointestinal diseases was considered. On the one hand, the pathology of the digestive system by changing the parameters of the internal environment of the body, has a significant impact on oral health, on the other hand, according to clinical data pathological processes in the mouth become foci of chronic infection, and violating the act of chewing, lead to dysfunction of the gastrointestinal tract and its exacerbation of chronic diseases.

Key words: diseases of the digestive tract, oral cavity, caries, periodontium. 
Ще І. П. Павлов (1898) у класичних роботах із вивчення органів травлення довів існування рефлексів з органів черевної порожнини в порожнину рота, коли при операційних втручаннях на шлунку в собак, отримав ураження слизової оболонки порожнини рота. На сьогодні відомо, що рецептори слизової оболонки ротової порожнини є потужним джерелом нервових імпульсів, що впливають на секреторну і моторну діяльності шлунка і кишечника. Одночасно з цим, порожнина рота $є$ ефректорним полем зворотного впливу «патологічних» рефлексів із внутрішніх органів.

Взаємозв'язок нижніх відділів шлунковокишкового тракту і його початкового відділу - порожнини рота - здійснюється за допомогою анатомічних, фізіологічних і гуморальних зв' язків. У поодиноких роботах дані зв' язки підтверджені наявністю поєднаних передракових захворювань СОПР і ШКТ, а конкретно: лейкоплакія СОПР - лейкоплакія стравоходу, хронічний атрофічний езофагіт, хронічний атрофічний гастрит, папіломатоз СОПР - поліпи прямої кишки.

У зв'язку з цим, в останні роки особливу увагу дослідників у сфері стоматології та гастроентерології зосереджено на проблемі участі порожнини рота у розвитку захворювань ШКТ, тому що, з одного боку, патологія травної системи, змінюючи параметри внутрішнього середовища організму, робить істотний вплив на стан порожнини рота.

3 іншого боку, згідно 3 клінічними даними, патологічні процеси в порожнині рота стають вогнищами хронічної інфекції, i, порушуючи акт жування, призводятьдо порушення функції ШКТ і загострення його хронічних захворювань. В організмі таких хворих фрормується порочне коло: захворювання порожнини рота погіршують перебіг хронічної патології ШКТ, а хронічні захворювання травної системи, викликаючи різного ступеня дефіцит пластичних і енергетичних речовин, посилюють тяжкість патології органів порожнини рота.

Ряд авторів $[2,5]$ розглядає порожнину рота як своєрідну екологічну систему, в якій різні чинники - загальні й місцеві - спільно взаємодіючи, викликають різноманітні патологічні процеси.

За даними низки авторів, зміни в порожнині рота відображають закономірності патогенезу системної патології і зумовлені етіологічною, морфологічною та функціональною інтеграцією всіх систем організму.
3 цієї причини проблема діагностики та лікування патології органів порожнини рота i виходить за межі стоматології. А знання особливостей проявів захворювань внутрішніх органів у порожнині рота важливо Аля лікарястоматолога в плані діагностики та 3 метою розробки комплексних підходів при лікуванні даної патології.

Ряд дослідників виявив більш високу поширеність карієсу, захворювань слизової оболонки порожнини рота, тканин пародонта в дітей і у дорослих осіб із запально-деструктивними захворюваннями шлунка та кишечника.

Так, виявлено у дітей із хронічними гастродуоденітами високе поширення карієсу, погану гігієну порожнини рота, зниження рН слини і показників стану місцевого імунітету.

Аеякі дослідження вказують на те, що патологія ШКТ впливає на порушення розщеплення основних компонентів їжі та їх всмоктування, що призводить до ендогенного збіАнення організму білками, жирами, вуглеводами, мінеральними компонентами, тобто до високої поширеності карієсу зубів у досліджуваної групи пацієнтів.

Роботи О. ^. Піхур показали, що карієсу постійних зубів у дітей із патологією ШКТ не виявлено тільки в 21,6 \% проти 29,4% у дітей без захворювань органів травлення.

Більш високу поширеність та інтенсивність карієсу зубів у дітей із гастродуоденітом відзначено і в дослідженнях А. П. Петрової. Автор описує гіпосалівацію на тлі зниження вмісту кальцію у слині й ацидозу. Висловлюють припущення про вплив вмісту шлунка та дванадцятипалої кишки при рефлюксі на гомеостаз порожнини рота, базового слиновиділення, а також активацію демінералізуючих властивостей слини.

У роботах Н. В. Березиної встановлено пряму кореляційну залежність між нозологічною формою захворювання та індексами інтенсивності карієсу та гігієни порожнини рота у дітей із патологією ШКТ.

В. В. Гунчев виявив низький рівень стоматологічної допомоги (РСА) у дітей із патологією ШКТ - 38,9% (Аля порівняння у здорових $-97 \%)$.

Т. О. Ааміна показала, що в дитячому віці патологію ШКТ не тільки зумовила зміна фізичного розвитку і помітно вплинула на стан зубощелепного апарату та щелепнолицевої зони в цілому. Автори доводять, що чим раніше виникає і розвивається патологія

ISSN 23 1-9624. Кпінічна стоматопогія. 2014. № 2 
ШКТ, тим більш значущі не тільки порушення в щелепно-лицевій ділянці, але і відставання у фізичному розвитку, що дозволяє зробити висновок: «Якщо причиною відставання дитини у фізичному розвитку і дефрормації щелепно-лицевої ділянки є патологія ШКТ, то патологія зубощелепної системи та щелепнолицевої ділянки або підтримує патологію ШКТ, або сприяє подальшому її прогресуванню. Створюється порочне коло, в якому причина і наслідок постійно міняються місцями».

При вивченні впливу патології шлунковокишкового тракту на стан порожнини рота у дорослих пацієнтів дослідники звертають увагу на інтенсивність карієсу, стан тканин пародонта, гігієнічний стан порожнини рота, показники місцевого імунітету, деякі показники слини.

Багато авторів відзначає інтенсивність карієсу при гастритах і ВX від 5 до 22. Таке високе ураження зубів у хворих на ВХ карієсу пояснюється наявними у даній групі пацієнтів із гастроезофагіальним рефлюксом, що сприяє закиданню шлункового соку в порожнину рота і розвитку карієсу й некаріозних захворювань, зокрема ерозії емалі зубів.

Білыш широка увага приділяється проблемам пародонта при порушенні функції травної системи. За різними літературними даними, патологія пародонта виявлялася у 92 - 100 \% пацієнтів.

У літературі є вказівки на несприятливий вплив на пародонт таких захворювань, як гастрит, виразкова хвороба шлунка та дванадцятипалої кишки.

Відзначається швидка генералізація процесу, прогресування змін зі значними порушеннями в імунному статусі хворих. У пацієнтів із хронічними гастритами та виразковою хворобою виявлено нестабільне слиновиділення, що призводить до зниження процесів самоочищення в порожнині рота і посилює перебіг хронічного катарального гінгівіту.

ОАнак у більш пізніх дослілженнях $\lambda$. А. Вейсгейм, Є. В. Люмкіс відзначають, що захворювання пародонта при патології ШКТ зустрічаються у 68 - 90 \% обстежених пацієнтів, а виразкова хвороба шлунка та дванадцятипалої кишки - із захворюваннями пародонта навіть при задовільному стані порожнини рота.

Ступінь запально-деструктивних процесів у пародонті корелює з активністю запалення в ШКТ, що може бути єдиним процесом запального генезу, реалізується за участю дифузної нейроендокринної системи травного тракту з одного боку , а з іншого боку - через процеси проліферації та апоптозу епітеліоцитів.

Поєднання хвороб шлунка та дванадцятипалої кишки з поганою гігієною порожнини рота і дефектами зубних рядів суттєво впливають на розвиток патологічних процесів у тканинах пародонта. Так, 57 \% хворих із порушеннями фрункції жування з приводу вторинного зниження прикусу склали пацієнти із патологією ШКТ, 48 \% з них були з хронічним гастритом, 30 \% - із виразковою хворобою і 23 \% з жовчнокам'яною хворобою.

Ряд авторів $[3,6]$ вважає, що вираження захворювань пародонта залежить від характеру перебігу виразкової хвороби - спочатку проявляється гінгівіт і пародонтит легкого ступеня, при тривалому перебігу - середнього та тяжкого ступеня, причому головною особливістю захворювань пародонта на тлі хронічних уражень ШКТ, в тому числі ВХ, є більш рання генералізація патологічного процесу.

Аеякі автори відзначають взаємоускладнювальний характер перебігу генералізованого пародонтиту та виразкової хвороби.

У свою чергу, дослідники спостерігали при всіх типах перебігу виразкової хвороби кореляційну залежність між вираженням ураження пародонта і ступенем порушення регуляції обміну кальцію крові (вміст кальцію, тирекальцитоніну, фттору).

На можливість функціонального взаємозв'язку і взаємозумовленості між змінами пародонта і станом секреторної й моторної діяльності шлунка вказував ряд авторів, пов'язуючи зміни в пародонті з пониженням кислотності шлункового соку. Г. Барер і співавт. пояснюють і захворювання твердих тканин зубів й патологію тканин пародонта проявами ГЕРХ.

У розвитку патології тканин пародонта I. В. Козлова відлає перевагу гастроезофагальному рефлюксу і компонентам дифузної ендокринної системи порожнини рота і шлунка. За літературними даними, велика кількість випадків ерозивно-виразкових уражень шлунка та дванадцятипалої кишки супроводжується ГЕРХ.

K. С. Аесятниченко вважає порушення моторики травного тракту, що призводить до закидання шлункового вмісту в ротову порожнину, основним чинником виникнення порушень у ротовій порожнині. 3 іншого боку, на думку цього ж автора, порушення підготовки харчової грудки через недостатню 
салівацію та зниження жувальної функції і є умовами антиперистальтики.

На думку ряду авторів [1, 3], фракт погіршення гігієнічного стану порожнини рота в осіб із патологією травної системи може змінювати біохімічний склад ротової рідини і, зокрема, впливати на ураження зубів карієсом.

Роль слини в даний час є незаперечною у підтримці фізіологічних і розвитку патологічних процесів твердих і м'яких тканин порожнини рота.

На думку П. А. Леус, на зуб можуть впливати так звані загальні та місцеві фактори, в тому числі й загальний стан організму, надаючи свою дію на можливий розвиток стоматологічної патології опосередковано через слину. Саме тому вивчення властивостей слини при патології травної системи є основним моментом у формуванні патогенетичної вертикалі стоматологічної патології у досліджуваної групи пацієнтів.

Більшість робіт, присвячених вивченню властивостей слини при патології ШКТ, у тому числі при ВХ, було проведено в 50 - 80-ті роки ХХ століття. В основному роботи дослідників присвячені швидкості секреції слини і її складу в осіб з ВХ як із захворюванням травної системи, яке найчастіше зустрічається. У дослідників немає єдиної думки щодо досліджуваних питань. Розбіжності зберігаються і сьогодні. Це пов'язано з певними труднощами в оцінці функції слинних залоз, так як слиновиділення є дуже варіабельною величиною у нормі. Зокрема, дослідження показують, що у хворих із хронічним катаральним гінгівітом на тлі патології ШКТ слиновиділення нестабільне: періоди гіперсалівації на голодний шлунок чергуються зі зниженням кількості слини після споживання їжі порівняно з контролем.

Aле М. М. Пожарицька відмічає зниження швидкості секреції змішаної слини лише 3 віком, причому в чоловіків швидкість секреції слини зберігається на більш високому рівні, ніж у жінок.

При ВХШ і ВХАК у перший рік спостерігається гіперсалівація, а також при тривалому перебігу ВХ (більше 10 років). Інші автори вказують на зниження обсягу змішаної слини при ВХАК. Нестабільність слиновиділення у пацієнтів із виразковою хворобою і хронічним гастритом відзначає також [3], що позначається на зниженні процесів самоочищення у порожнині рота. 3 цих даних видно, що зміни секреторної функції слинних залоз дуже різноманітні й частіше залежать від стадії захворювання.

За даними А. П. Петрової, у дітей з гастродуоденітом відмічали знижену швидкість салівації більш ніж в 2 рази при зсуві рН слини у бік ацидозу і зниженні рівня кальцію слини в середньому на 30 \%, підтверджуючи думку про вплив шлункового і дуоденального рефлюксанта на гомеостаз порожнини рота, активацію демінералізуючих властивостей слини.

Однак дане питання широко дискутується, так, на думку Н. Ю. Перової, кислотно-лужний стан порожнини рота не корелює з кислотоутворювальною функцією шлунка. Очевидно, дана проблема потребує подальшого вивчення.

Також увагу дослідників привертає зміна рН слини, як головного природного регулятора біохімічних процесів у порожнині рота. Встановлено, що видимий демінералізуючий ефект емалі зубів спостерігається при значенні pH у порожнині рота рівному 6,0 і нижче, а час ремінералізації емалі, залежно від умов, може коливатися віддекількох годин до 30 діб, що може відіграти провідну патогенетичну роль у виникненні карієсу зубів.

Відзначено, що при виразковій хворобі шлунка і дванадцятипалої кишки [4] рН ротової рідини збільшено до 7,36 - 8,55, при хронічних гастритах - до 6,81, Аля порівняння у здорових $-7,08$.

Н. Ю. Перова вважає, що у пацієнтів із гіперхлоргідричним типом секреції знижена салівація, при гіпохлоргідричному типі гастральної секреції вона відзначена зменшенням швидкості секреції слини і зниження їі pH.

У більш ранніх роботах W. D. Rees et al. пояснюють збілышення концентрації бікарбонатів у слині паралельно з підвищенням кислотоутворювальної функції шлунка. Причому в фразі загострення ВX, що перебігає з підвищеною кислотністю, відзначається гіперплазія слинних залоз, що є, ймовірно, компенсаторною реакцією, спрямованою на нейтралізацію соляної кислоти шлункового соку бікарбонатами слини.

На думку низки авторів [1, 2, 6], на патогенез основних стоматологічних захворювань впливає не стільки склад і вміст окремих компонентів слини, а більшою мірою її комплексні властивості, а саме: швидкість секреції слини, реологічні властивості слини (в'язкість, поверхневий натяг слини), рівень мінералізації та ін. 
Кількісний та якісний склад змішаної слини певною мірою визначає збереження гомеостазу порожнини рота. Тік слини перешкоАжає прикріпленню патогенних мікроорганізмів до поверхні епітелію і видаляє колонізовані ними клітини. Встановлено, що слина має гідролізуючу, захисну і трофічну дії на слизову оболонку ясен і порожнини рота, тому гіпосалівація сприяє швидкому розвитку патологічних процесів у порожнині рота.

На функцію слинних залоз, склад і властивості змішаної слини, у свою чергу, сильно діє харчовий фактор, зокрема споживання їжі рослинного або тваринного походження, а також легкозасвоюваних вуглеводів. Також споживання деяких продуктів харчування може змінювати і рН зубного нальоту.

Місцевий імунітет слини, що забезпечує ефрект захисту порожнини рота, вивчено менше. Встановлено, що пацієнти з ВХ у 98 \% мають комбіновану недостатність імунної системи. Невідомо, що є первинним чинником - захворювання внутрішніх органів $з$ подальшим ураженням порожнини рота або можлива зворотна залежність. Вираження імунологічних відхилень автори пов' язують з локалізацією виразки, характером і періодом перебігу ВХ, а також із клінікою пародонтиту.

Важлива роль серед компонентів імунного захисту порожнини рота належить неспецифічним гуморальним фракторам $[3,5]$, що продукуються різними клітинами. Ао них належать так звані фактори природної резистентності: лізоцим, лактоферин, лактопероксида-

\section{Список літератури}

1. Патогенетичні механізми кореляції стресорного пошкодження пародонта та шлунка / ^.М.Тарасенко, I. М. Скрипник, К. С. Непорада // Фізіологічний журнал. -2000 . - Т. 46, № 4. - С. $76-79$.

2. Индивидуальные особенности стрессорной реакции органов пищеварения, связанные с типом реагирования нервной системы / $\Lambda$. М. Тарасенко, К. С. Непорада, И. Н. Скрыпник, Т. А. Петрушанко // Архив клинической и экспериментальной медицины. - 2000. - T. 9, № 1. - С. 103-105.

3. Зависимость реакции соединительной ткани на стресс от типологических свойств организма / А. М. Тарасенко, К. С. Непорада, И. Н. Скрыпник [и Ар.] // Патол. физиология и эксперим. терапия. 2000. - № 2. - С. $17-19$.

4. Взаємозв'язок морфофункціональних змін в органах системи травлення за умов стресорних впливів / за, муцин, інтерферон, деякі компоненти комплементу та ін. Всі ці фрактори наявні у слині в значних кількостях і беруть безпосередню участь у знищенні або придушенні життєдіяльності мікроорганізмів. Зазначені компоненти діють комплесно, багато в чому дублюють один одного, що підвищує кінцевий ефект захисту.

Однак при описі зазначених властивостей слини дослідники дотримуються, головним чином, їх змін при різних видах стоматологічної патології, не враховуючи загальний стан організму.

Таким чином, після огляду зазначеної літератури, визначається єдина думка дослідників про високу стоматологічну захворюваність високу інтенсивність карієсу і високі індексні показники стану пародонта - дітей і дорослих пацієнтів із виразковою хворобою і гастродуоденітом. У деяких роботах роблять спробу пояснити стоматологічну патологію наявними соматичним захворюванням, або використовувати окремі показники слини або крові як скринінг-діагностики.

Проте в основному роботи стосуються таких захворювань, як гастрит, дуоденіт або запально-некротичне ураження, яким є виразкова хвороба. Аосліджень, що вказують на взаємозв'язок деструктивно-запальних процесів гастродуоденальної зони, тобто ерозивних уражень, і стану порожнини рота, немає. Також відсутні роботи про вплив поєднаних показників інтрагастрального середовища і ротової порожнини, що актуалізує вивчення цієї проблеми.

I. М. Скрипник, К. С. Непорада, А. М. Тарасенко // Фахове видання наукових праць II Національного конгресу анатомів, гістологів, ембріологів і топографоанатомів України “Актуальні питання морфології". - Ауганськ, 1998. - С. 221.

5. Изменение реологических свойств циркулирующей крови в пульпе зубов человека при пародонтите / Е. В. Ковалев, В. А. Зюзин, Т. А. Петрушанко, 3. Ю. Назаренко : мат. II Международной конф. «Микроциркуляция и гемореология». - Ярославль Москва, 1999. - С. $131-132$.

6. Regulatory peptided as modulators of stressor injuries / L. M. Tarasenko, T. A. Devyatkina, K. C. Neporada [et al.] // The abstract programme of the $2^{\text {nd }}$ Parnas Conference. - Gdansk, Arthur's ourt, 1998. - P. 25. 